\title{
Provenance of the Upper Cretaceous to Lower Tertiary Sedimentary Relicts in the Renbu Mélange Zone, within the Indus-Yarlung Suture Zone
}

\author{
Guangwei Li, ${ }^{1,2, \star}$ Mike Sandiford, ${ }^{1}$ Steven Boger, ${ }^{1}$ Xiaohan Liu, ${ }^{3}$ and Lijie Wei ${ }^{3}$ \\ 1. School of Earth Sciences, University of Melbourne, Victoria 3010, Australia; 2. State Laboratory for Continental \\ Tectonics and Dynamics, Institute of Geology, Chinese Academy of Geological Sciences, Beijing 100037, China; \\ 3. Institute of Tibetan Plateau Research, Chinese Academy of Sciences, Beijing 100085, China
}

\begin{abstract}
A B S T R A C T
The Upper Cretaceous to Lower Tertiary sediments in the Indus-Yarlung suture zone provide critical records on the history of accretion along the southern margin of Asia prior to, and during, the India-Asia collision. In this article, we report field and petrographic observations, in situ detrital zircon U-Pb ages, Lu-Hf isotopic analyses, and Cr-spinel electron microprobe data from the Upper Cretaceous to Lower Tertiary sedimentary rocks of the Renbu mélange zone in east Xigaze, southern Tibet. The Renbu mélange zone consists of two serpentinite mélange subzones separated by a mud-matrix mélange. Using similarities found in the compositions of detrital Cr-spinels and detrital zircon U-Pb ages, we propose to correlate the northern Renbu mélange subzone with the upper part of the Xigaze forearc basin. Detrital zircons from sandstones in the southern Renbu mélange subzone indicate an influx of Cretaceous-early Cenozoic zircon grains with juvenile Hf isotopic compositions, suggesting a provenance from the Lhasa terrane, especially the Gangdese arc. Compared to the mélange in the western Xigaze, our new results show that much younger sediments were deposited on the top of the accretionary wedge, with the youngest U-Pb age cluster including six single grains in the range of 64-53 Ma and a large peak at $67 \mathrm{Ma}$. Our results support the idea that the foreland basin developed along the Indus-Yarlung suture during the India-Asia collision.
\end{abstract}

Online enhancements: supplementary tables.

\section{Introduction}

Accretionary complexes record subduction, erosion, and deposition of sediment and accretion along active continental margins. Late Mesozoicearly Cenozoic accretionary complexes are thought to be exposed in the Tibetan Himalaya, where they provide important clues to the closure of the NeoTethys Ocean (Burg and Chen 1984; Aitchison 2000; Cai et al. 2012). There are two common scenarios proposed to explain the origin of these accretionary mélanges. One suggests that these complexes were formed in an oceanic subduction zone beneath the southern margin of the Asian continent and/or under the suprasubduction Indus-Yarlung ophiolite prior to being obducted onto the Tethyan

Manuscript received May 19, 2014; accepted December 9, 2014; electronically published January 22, 2015.

* Author for correspondence; e-mail: guangwei.li@unimelb .edu.au.
Himalayan (Burg and Chen 1984; Cai et al. 2012; Hébert et al. 2012; Wang et al. 2012). The other proposes that the complexes formed in an intraoceanic arc during the Eocene (Aitchison 2000; Aitchison et al. 2007). These interpretations in turn lead to very different scenarios for the progressive closure of the Neo-Tethys Ocean (Aitchison 2000; Ding et al. 2005; Aitchison et al. 2007; Najman et al. 2010). Fragments of the early Cenozoic (PaleoceneEocene) sediments preserved in the mélanges probably recorded the India-Asia collision process and are probably part of the proposed Paleocene-Eocene foreland basin system in south Tibet located near the accretionary complexes of the Indus-Yarlung suture zone (Ding et al. 2005, 2009; DeCelles et al. 2014).

In this article, we investigate the Renbu mélange, located in the eastern Xigaze region, along the Indus-Yarlung suture zone (fig. 1). We present

[The Journal of Geology, 2015, volume 123, p. 39-54] (C) 2015 by The University of Chicago. All rights reserved. 0022-1376/2015/12301-0003\$15.00. DOI:10.1086/680207 


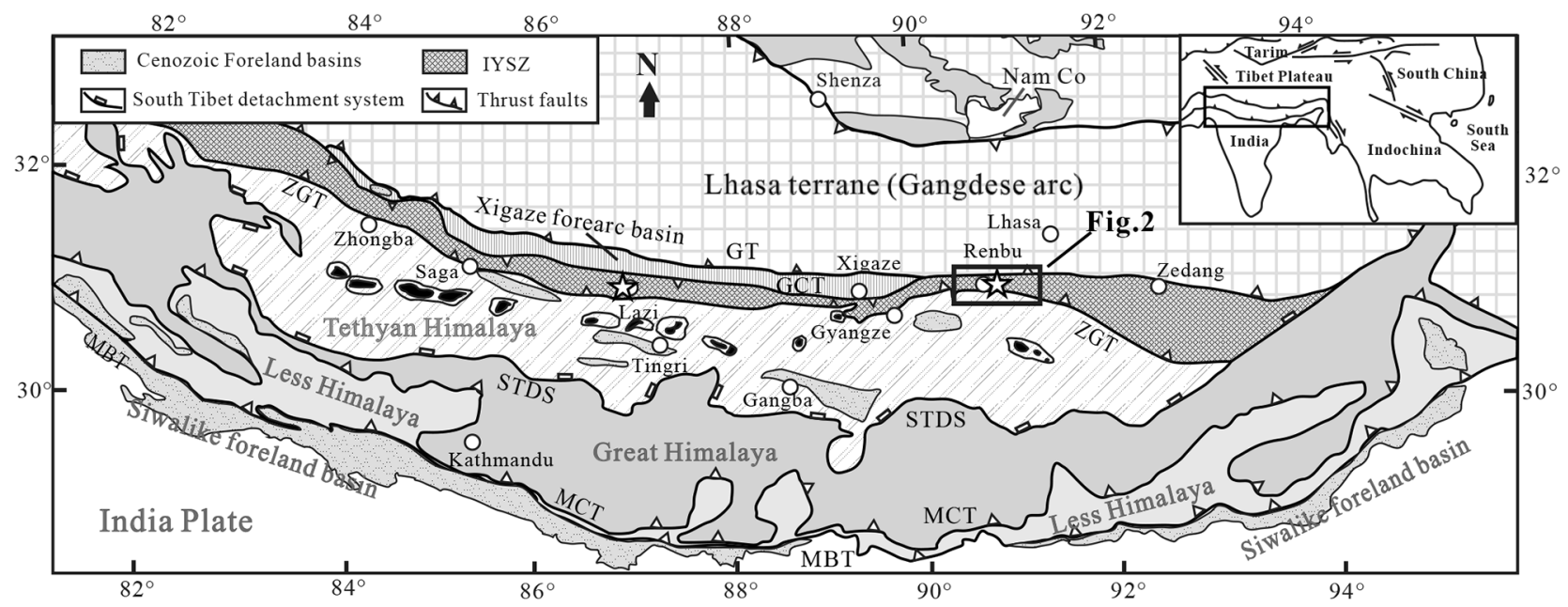

Figure 1. Simplified tectonic map and distribution of the upper Cretaceous-Cenozoic basins in the Himalayan orogenic belt, south Tibet (modified after Ding et al. 2009). From north to south, the main strata in these basins include the Tso-Jiangding Group (low Tertiary) in the north of the Zhongba area; the upper Zhongzuo formation (latest Cretaceous) and Zheba group (Paleocene-Eocene) in the Saga-Gyangze zone; the Zongpu Formation (Late Cretaceous), Jidula sandstone formation (Maastrichtian-Paleocene), Zhepureshanpo limestone formation, and Pengqu formation in the Gangba-Tringri zone; and the Siwalike foreland basin (e.g., Willems et al. 1996; DeCelles et al. 2000, 2004; Wan et al. 2002; Ding 2003; Ding et al. 2005, 2009; Najman 2006; Cai et al. 2011). GT, Gandese Thrust; GCT, Great Counter Thrust; ZGT, Zhongba-Gyantse Thrust; STDS, South Tibetan detachment system; MCT, Main Central Thrust; MBT, Main Boundary Thrust; IYSZ, Indus-Yarling suture zone.

new field and petrographic observations and Crspinel analysis in combination with in situ U-Pb-Hf isotopic analyses of detrital zircons to help discriminate the different components of the accretionary complex. We show that the younger sediments, dating to the Upper Cretaceous to Lower Tertiary, represent components of the foreland basin along the Indus-Yarlung suture sourced from the southern Asian Lhasa terrane and provide new constraints on the evolution of the India-Asia collision.

\section{Geologic Setting}

The Renbu tectonic mélange is part of the IndusYarlung suture zone, sandwiched between the Lhasa terrane to the north and the Tethyan Himalaya to the south (fig. 1). The Indus-Yarlung suture zone marks the remnants of the Neo-Tethys Ocean and thus represents the boundary between the Indian and Asian plates (Burg and Chen 1984; Yin and Harrison 2000). This suture zone is bounded by the Great Counter Thrust and the Zhongba-Gyantse thrust (Yin 2006) and is defined by ophiolitic rocks of late Jurassic to early Cretaceous age (Aitchison 2000; Malpas et al. 2003; Miller et al. 2003; DuboisCôté et al. 2005; Wang et al. 2006; Aitchison et al. 2007). These ophiolitic rocks are associated with late Jurassic-early Cretaceous island-arc volcanic rocks (McDermid et al. 2002; Aitchison et al. 2007) and the controversial Liuqu Conglomerate (Davis et al. 2002; Fang et al. 2006; Wei et al. 2011). The ophiolitic rocks are locally in thrust contact with a 10- to 50-km-wide mud-matrix turbidite mélange exposed in the hanging-wall Zhongba-Gyantse or Lhunze thrusts (Ding et al. 2005; Yin 2006; Li et al. 2010, 2011; Dunkl. et al. 2011; Cai et al. 2012; figs. 1,2). The coherent blocks of sedimentary strata found within this mud-matrix mélange form the focus of this study.

The Xigaze basin is exposed immediately north of the Indus-Yarlung suture zone and is fault bounded by the Gandese Thrust to the north and the Great Counter Thrust to the south. The basin consists of Cretaceous and Lower Tertiary strata that are further divided from oldest to youngest into the Xigaze (in a forearc-basin setting) and TsoJiangding (in a foreland-basin setting; Ding et al. 2005) groups. The lower part of the Xigaze Group, consisting of the Chongdoi and Ngamring formations, is comprised mainly of sandstone and shale, with some intercalations of marly limestone and conglomerate. These rocks are interpreted to have been deposited in a deep marine environment (Einsele et al. 1994). The upper part of the Xigaze Group, defined by the Panada and Qubeiya formations, consists of sandstone, mudstone, and interlayered limestone interpreted to have been deposited in 

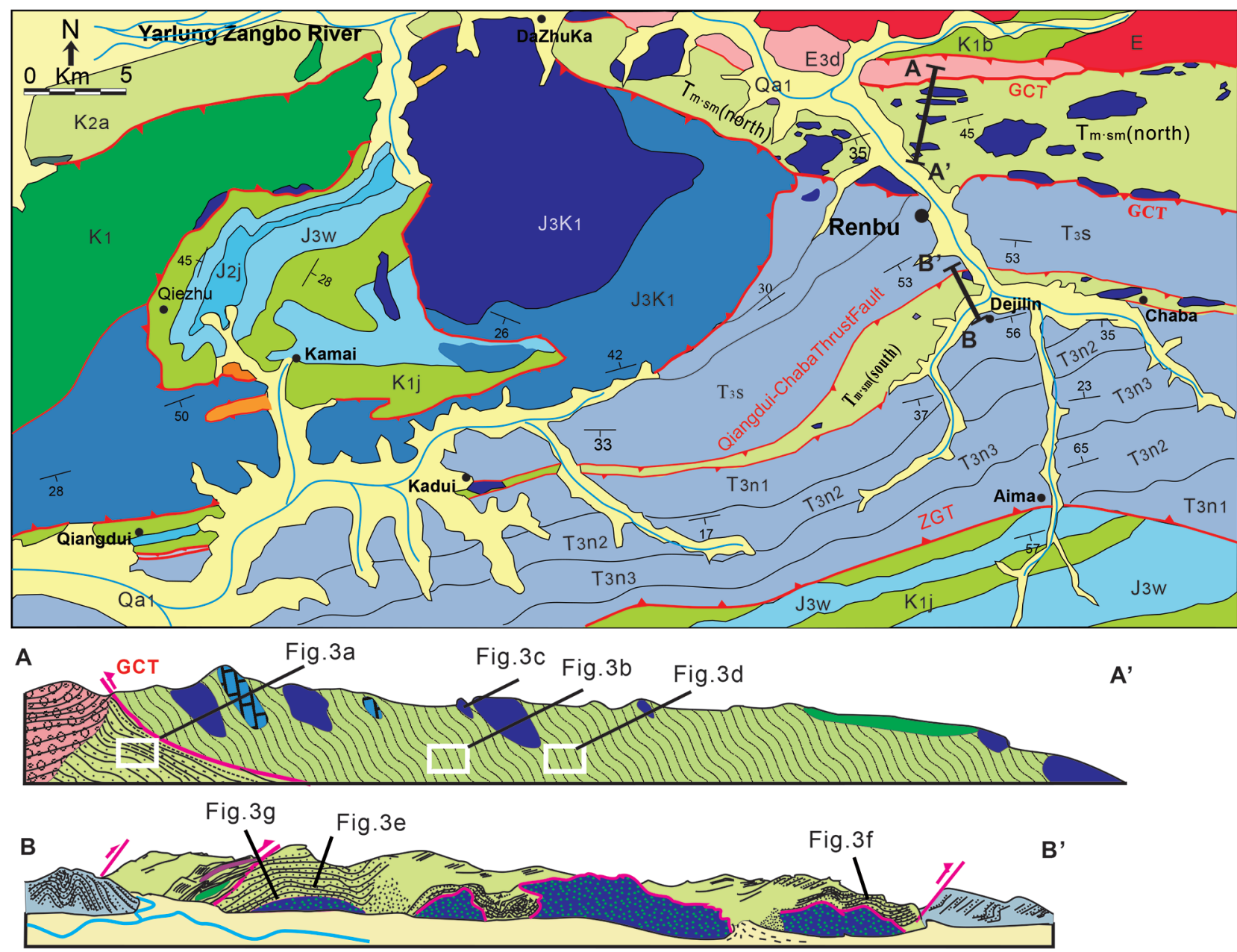

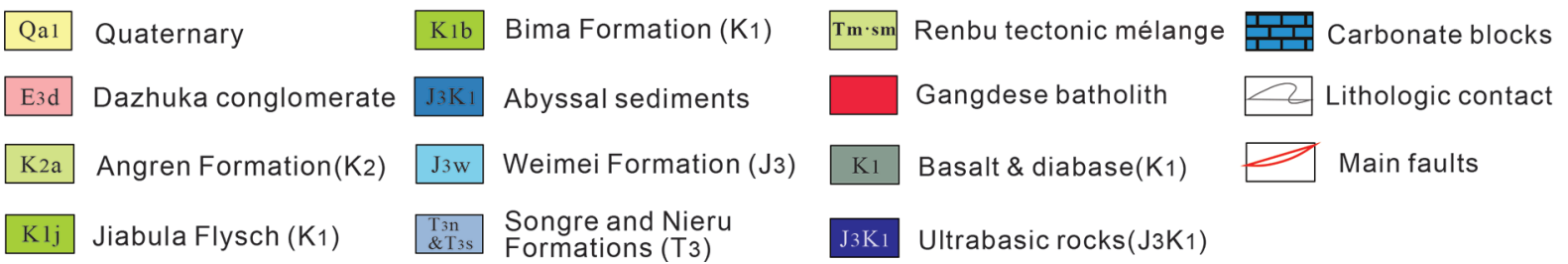

Figure 2. Geological map and profile of Renbu area. $A, \mathrm{~A}^{\prime}$ represents the section of the northern Renbu mélange subzone (Xima-Dazhuka subzone). $B, \mathrm{~B}^{\prime}$ is the section of the southern subzone (Dejilin-Kadui subzone) between the Songre $\left(\mathrm{T}_{3 \mathrm{~s}}\right)$ and Nieru $\left(\mathrm{T}_{3 \mathrm{n}}\right)$ formations. GCT, Great Counter Thrust.

a shallow marine environment (Ding et al. 2005; Wu et al. 2010). The lower Tertiary Tso-Jiangding Group unconformably overlies the Xigaze Group and generally shows upward fining from conglomeratic strata at the base to sandstone and limestone with lesser conglomerate in the upper part of the sequence (Einsele et al. 1994; Liu and Ensele 1994; Ding et al. 2005; Wang et al. 2012; fig. 1). These young rocks are inferred to have been deposited in the residual foreland basin after the India-Asia collision (Ding et al. 2005). Most of the sediments in the Xigaze basin are thought to be sourced from
Lhasa terrane (Dürr 1996; Wu et al. 2010; Wang et al. 2012).

The Lhasa terrane crops out north of the Xigaze basin and the Indus-Yarlung suture zone and includes local exposures of Proterozoic and Early Cambrian basement (Dewey et al. 1988; Harris et al. 1988; Guynn et al. 2006). The southern Lhasa terrane (Yang et al. 2009) is comprised predominantly of Mesozoic-Cenozoic igneous rocks of the Gangdese arc Late Cretaceous to Eocene arc-related volcanics, volcaniclastics, and interbedded fluvial lacustrine sediments of the Linzizong group /Chu 
et al. 2006; Mo et al. 2007; Ji et al. 2009; Zhu et al. 2009). These rocks are locally overlain by Cenozoic sediments. The northern Lhasa terrane is comprised of mostly upper Palaeozoic-Cretaceous sediments, although it includes localized exposures of Paleozoic and Mesozoic igneous rocks (Leier et al. 2007; Zhu et al. 2013; Li et al. 2014).

The rocks of the Tethyan Himalaya, exposed to the south of the Indus-Yarlung suture, are bounded by two major fault systems: the north-dipping South Tibetan detachment and the north-dipping Zhongba-Gyantse thrust (Ding et al. 2005; Yin 2006; fig. 1). A distinctive structural feature of the Tethyan Himalaya is the Northern Himalayan Gneiss domes system, which consists of CambrianOrdovician medium- to high-grade metamorphic rocks intruded by 44-10 Ma leucogranites (e.g., Chen et al. 1990; Lee et al. 2004; Quigley et al. 2008; Zeng et al. 2011). The Tethyan Himalaya is comprised mainly of Palaeozoic-Cenozoic sandstones and mudstones, shales, and limestones. The Palaeozoic-Mesozoic strata are interpreted to represent the Indian passive continental margin shelf deposits in the south, grading northward into continental slope deposits (Liu and Einsele 1994; Wan et al. 1997; Ding 2003). The uppermost Cretaceous to Eocene strata (upper Zhongzuo, Sangdanlin and Zheba formations) to the north consist of a succession of shale and coarse-grained sandstones interbedded with lenses of planktonic-benthic foraminiferabearing limestone and radiolarian chert (Wan and Ding 2002; Ding et al. 2005, 2009; fig. 1), regarded as part of the foreland basin in the Indus-Yarlung suture (Ding et al. 2005, 2009; DeCelles et al. 2014).

\section{Tectonostratigraphic Units of the Study Area}

The study area is located in the Indus-Yarlung suture zone, with the key exposures near Renbu (fig. 2). The study area incorporates the largest exposed ophiolite body of the Indus-Yarlung suture as well as a number of smaller inliers of these rocks exposed to the east of the main body of ultramafic rocks. The most recent geological surveys of this area have defined a tectonic mélange (Renbu tectonic mélange: Trm.sm) that separates the IndusYarlung ophiolite from the Late Triassic flysch defined by the Nieru $\left(T_{3 n}\right)$ and Songre $\left(T_{3 s}\right)$ formations. The mélange zone is divided into the northern Xima-Dazhuka and southern Dejilin-Kadui subzones (Hu 2002; Li et al. 2010, 2011; fig. 2). The matrix of the mélange consists of the slate and sandstone as well as discrete blocks of serpentinized dunite, diabase, basalt, and chert interpreted to define relicts of the Indus-Yarlung ophiolite. Other less common exotic blocks include dolomitic limestone and sandstone.

The northern subzone of the Renbu mélange is in fault contact with the conglomerates of the Oligocene-MioceneDazhuka Formation $\left(\mathrm{E}_{3} \mathrm{~N}_{1}\right.$; Wang et al. 2013), Cretaceous basalt and diabase $\left(\mathrm{K}_{1}\right)$, and the Eocene granitoids of the Gangdese batholith. The southern boundary of the northern subzone is defined by the Great Counter Thrust, which separates the mélange rocks from the Triassic Songre Formation (fig. 2). The rocks of the northern subzone are defined by the deformed bodies of JurassicCretaceous ultramafic and mafic rock, sparse red radiolarian chert, and some Permian marble. In addition, we have identified abundant blocks of Cretaceous sedimentary rock, which are mainly composed of two types. One is found in contact with the Dazhuka Formation (figs. 2, 3a) and includes medium- to thick-bedded sandstone that grades into limestone and mudstone/siltstone (figs. 2, 3). The other consists of the thin- to medium-bedded sandstone with interlayered limestone, together with abundant mudstone and shale. These rocks are strongly deformed and preserve structures, suggesting top-to-north transport (figs. 2, 3b, 3d).

The southern subzone of the mélange is exposed in the vicinity of Dejilin (fig. 2). This unit is fault bounded and lies between the Triassic Songre Formation $\left(\mathrm{T}_{3 \mathrm{~s}}\right)$ to the north and the Nieru Formation $\left(\mathrm{T}_{3 \mathrm{n}}\right)$ to the south (Hu et al. 2002; Li et al. 2010, 2011). Sedimentary blocks within the mélange, defined here as Dejilin sedimentary relict, consist mainly of well-layered green and gray siltstones and sandstones. These units nonconformably overlie the ophiolitic rocks (figs. 2, 3e-g) and define a sequence that is $\sim 40 \mathrm{~m}$ thick.

\section{Analytical Methods}

Zircon and spinel grains for isotopic and chemical analysis were separated from their host rocks by crushing and then purified to a concentrate via heavy liquid and magnetic techniques. Zircon was then handpicked and mounted in epoxy resin and ground to expose the centers of the grains. Cathodoluminescence images were taken and used to check the internal structure of individual zircon grains. U-Pb isotopic analyses were conducted at the school of Earth Sciences, the University of Melbourne, employing an Agilent 7500a quadrupole inductively coupled plasma mass spectrometer (ICP-MS), coupled to a 193-nm ArF excimer laser. Analytical methods follow those described by 

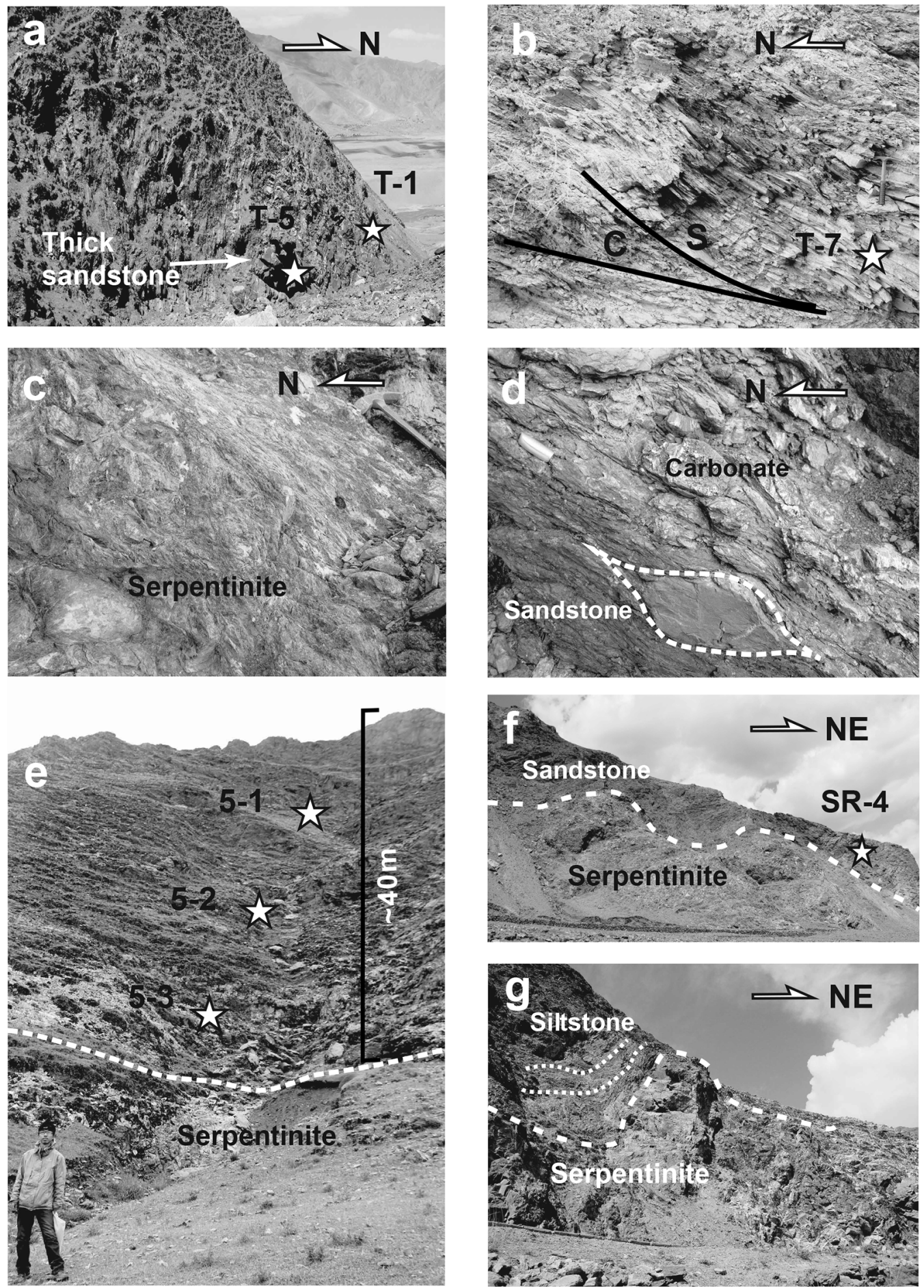

Figure 3. a, Sedimentary relicts with well-preserved strata in the northern Renbu mélange zone (Xima-Dazhuka subzone, XDS), immediately adjacent to the Dazhuka conglomerate. $b$, The thin midsandstone sequences in the XDS, and the s-c structure indicating top-to-north movement. $c$, The deformed serpentinite block in the XDS. $d$, The $\sigma$-type rotational textures from the sandstone interbedded with carbonate in the XDS showing top-to-north movement as well. $e$, The relationship between the upper part of the turbiditic sandstone and the middle part of the siliceous shale. $f$, The sedimentary relicts in the southern subzone (Dejilin-Kadui subzone, DKS). $g$, The contact between the sediments and serpentinite in the DKS. A color version of this figure is available online. 
Woodhead et al. (2004, 2007), Eggins et al. (2005), and Paton et al. (2010). The Plesovice (337 Ma), TEMORA (417 Ma), and 91500 (1064 Ma) zircon standards were analyzed, along with zircon unknowns to correct for U-Pb fractionation. Data reduction was conducted using the Iolite data reduction package, which runs within the Wave metrics IgorPro data analysis software (Hellstrom et al. 2008). Concordia plots were processed using Isoplot 3.0 (Ludwig 2003).

Lu-Hf isotopic analysis was undertaken with a $\mathrm{Nu}$ Plasma MC-ICPMS coupled to a HelEx laser ablation system utilizing a 193-nm ArF excimer laser. Zircon standard 91500 and TEMORA were used for external correction. The $\epsilon_{\mathrm{Hf}}$ and model ages reported here use ${ }^{176} \mathrm{Lu}$ decay constant $\lambda=1.867 \times$ $10^{-11} \mathrm{a}^{-1}$ (Scherer et al. 2001), $\left({ }^{176} \mathrm{Lu} /{ }^{177} \mathrm{Hf}\right)_{\mathrm{CHUR}}=$ $0.0332,\left({ }^{176} \mathrm{Hf} /{ }^{177} \mathrm{Hf}\right)_{\text {CHUR }, 0}=0.282772$ (Griffin et al. $2000),\left({ }^{176} \mathrm{Lu} /{ }^{177} \mathrm{Hf}\right)_{\mathrm{DM}}=0.0332$, and $\left({ }^{176} \mathrm{Hf} /{ }^{177} \mathrm{Hf}\right)_{\mathrm{DM}}=$ 0.282772 (Bichert-Toft and Albarède 1997).

Spinel composition was determined using a Cameca SX51 electron microprobe at the Institute of Geology, Chinese Geological Academy of Sciences. Analysis was undertaken using an accelerating voltage of $21 \mathrm{kV}$, a sample current of $10 \mathrm{nA}$, and the beam diameter of $5 \mu \mathrm{m}$. For the sandstones hosting zircon and spinel, petrographic analyses was undertaken using the Gazzi-Dickinson point-counting method (Dickinson 1985). More than 300 points were counted for each sample. The grain composition data is displayed in figure 4, while the isotopic and compositional data from zircon and spinel are presented in figures 5-7 and in supplemental tables S1-S5, available online.

\section{Results}

Sandstone Petrology. Three sandstone samples were collected from the northern subdomain of the Renbu mélange. All three samples are poorly sorted and contain grains showing mostly angular to subangular shapes. Quartz constitutes between 57\% and $66 \%$ of the rock and includes both monocrystalline and polycrystalline (chert) grains. Feldspar, which is commonly twinned, constitutes $9 \%-17 \%$ of the rock. Lithic clasts constitute $23 \%-25 \%$ of the rock and are defined by volcanic fragments, sedimentary clasts, and metamorphic lithics. All three samples plot within the recycled orogen provenance field on QtFL and QmFLt diagrams (fig. 4; table S3).

Three sandstone samples were collected and analyzed from the Dejinlin sedimentary relict within the southern subdomain of the Renbu mélange. These rocks are dominated by quartz grains and lithic clasts, which constitute $\sim 66 \%-75 \%$ and $\sim 13 \%-27 \%$ of the rock, respectively. Quartz is mainly monocrystalline $(>60 \%)$ and shows undulose extinction suggestive of a volcanic origin. Feldspar constitutes $\sim 5 \%-11 \%$ of the rock and is mostly twinned. The lithic fragments are predominantly of sedimentary origin. These constitute $5 \%-$ $14 \%$ of the rock volume and are mostly sandstone and mudstone. Comparatively lower percentages of volcanic $(2 \%-6 \%)$ and metamorphic lithic fragments $(5 \%-17 \%)$ were observed in these rocks when compared to the sediments from the northern zone of the Renbu mélange. Similar to the sandstones from the northern subdomain, the sandstones from

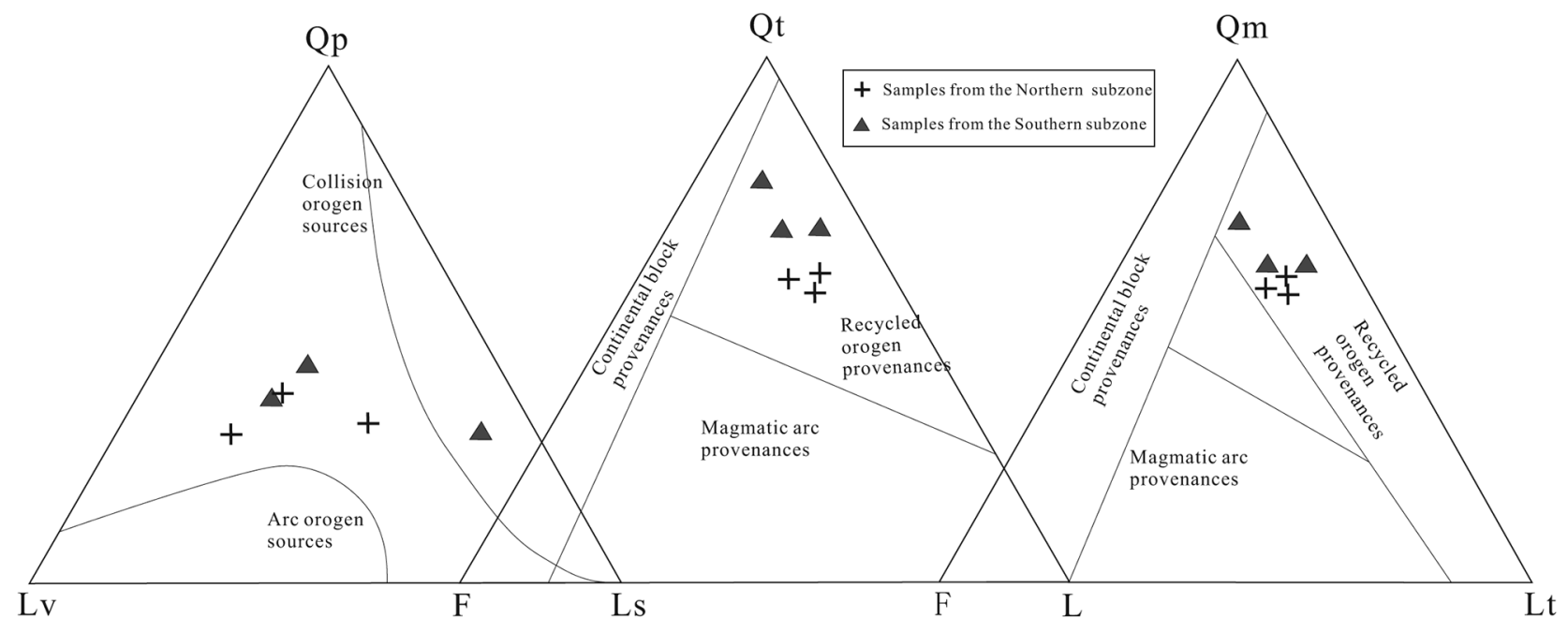

Figure 4. Petrographic discrimination of the sandstones from the Renbu mélange plotted on standard QpLvLs, QtFL, and QmFLt diagrams (Dickinson 1985). F, feldspar; L, lithic; Lt, total lithics; Ls, sedimentary lithics; Lv, volcanic lithics; Qm, monocrystalline quartz; Qp, polycrystalline quartz; Qt, total quartz. 

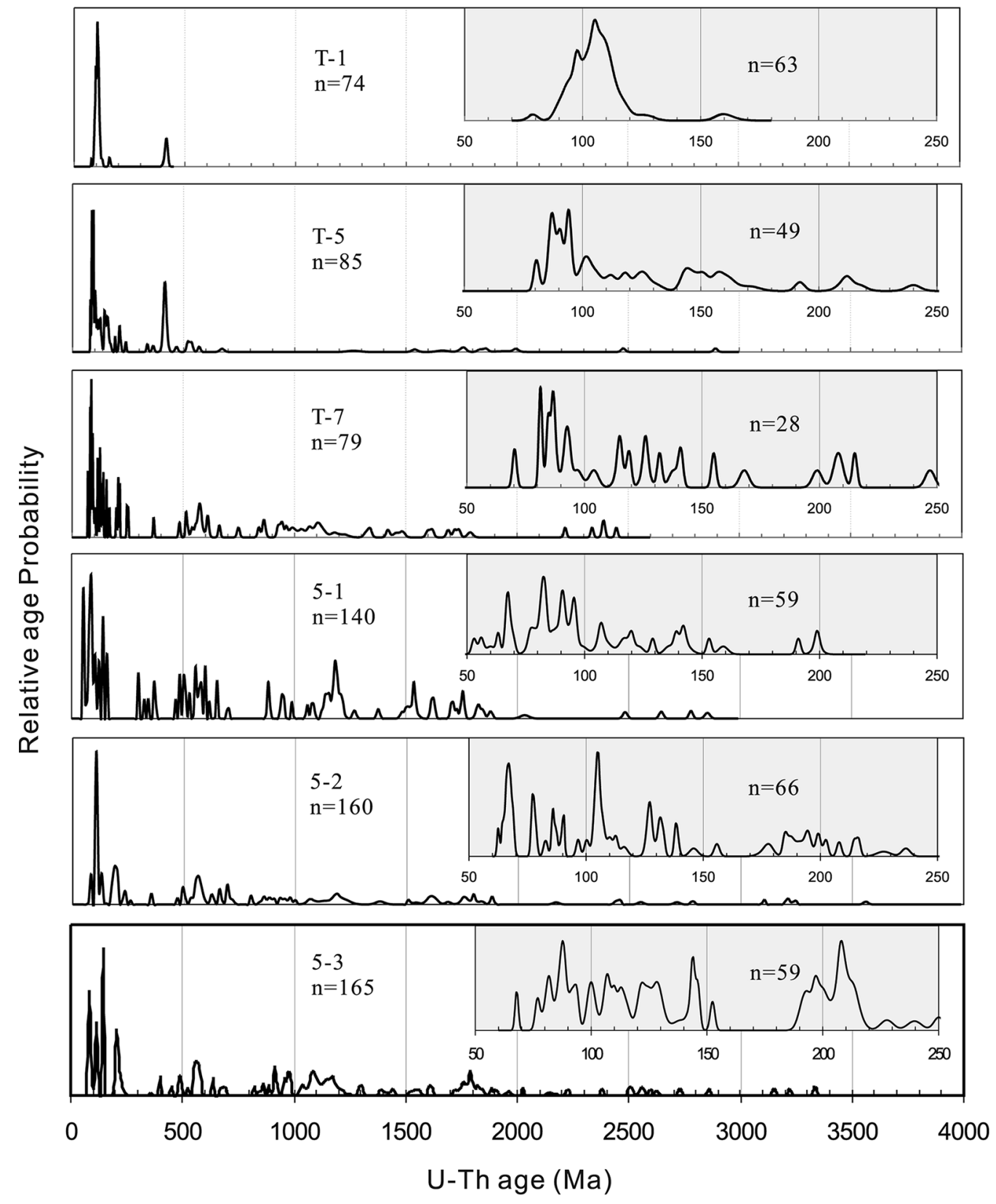

Figure 5. Relative age probability curves of detrital zircons of the sedimentary relicts from the Renbu mélange zone.

the southern subdomain plot in the recycled orogen provenance field on QtFL and QmFLt diagrams (fig. 4; table S3).

Heavy Mineral Assemblages. Two medium-finegrained sandstone samples (5-2 and 5-3) from the Dejilin sedimentary relict were used for heavy mineral assemblage analysis. The detrital heavy minerals are predominantly composed of zircon, apatite, tourmaline, rutile, octahedrite, leucoxene, magnetite, limonite, and sporadic pyrite and barite. No Crspinel was found. Sample 5-2 contains up to $28 \%$ apatite and lacks tourmaline, while sample 5-3 has a high tourmaline component (59\%). The calculated ATi value (Morton and Hallsworth 1994) is up to 100 for sample 5-2; it is 3 for sample 5-3. Sample 5-2 has an RZi value of 16, while sample 5-3 has a value of 7 (see table S4).

U-Pb-Hf Detrital Zircon Results. Three samples (T-1, T-5, and T-7) were collected from the northern subdomain of the mélange (figs. 2, 3a, 3b) and analyzed for U-Pb-Hf isotope compositions. Zircon grains for all samples are mainly euhedral and yield $\mathrm{Th} / \mathrm{U}$ ratios in a range between 0.14 and 4.7. Samples $\mathrm{T}-1$ and $\mathrm{T}-5$ were collected from sandstones 


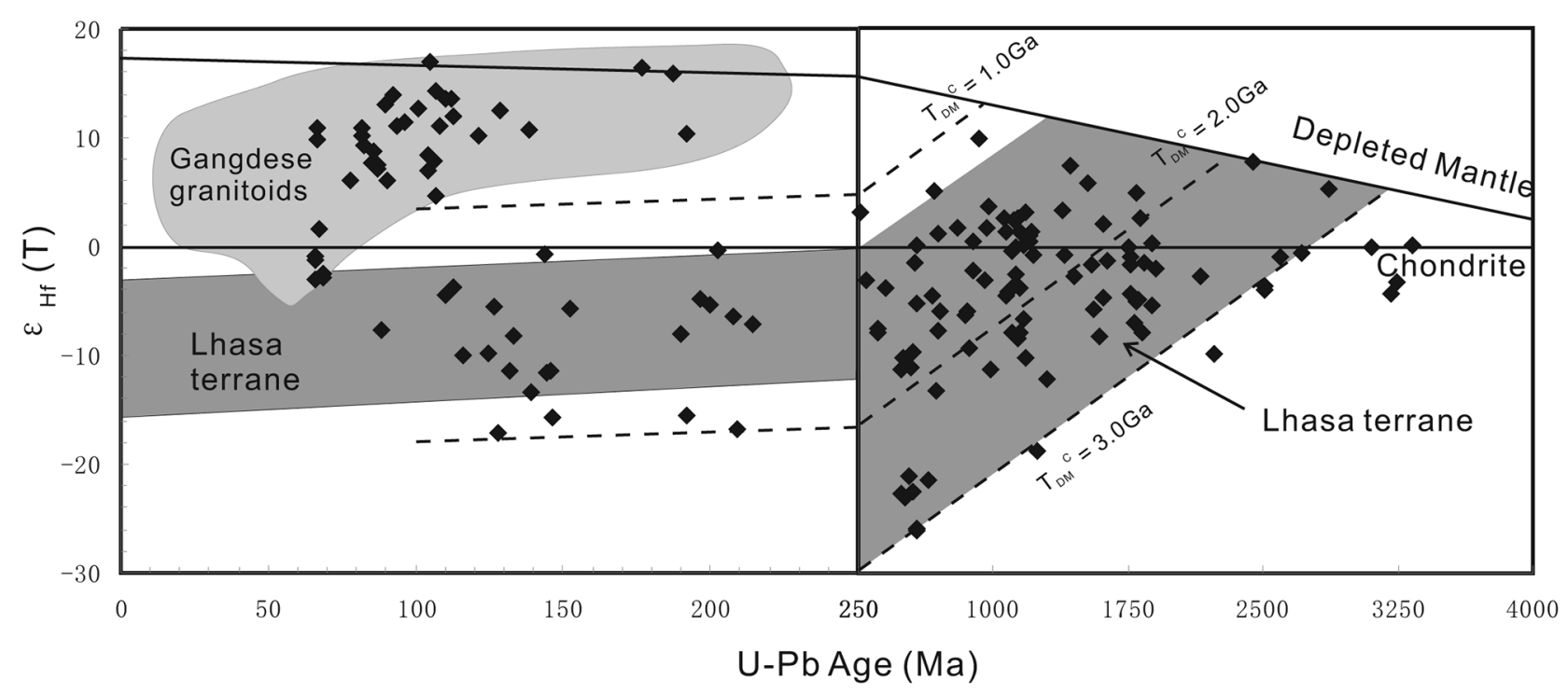

Figure 6. Hf isotopic features of detrital zircons from the Renbu mélange zone in the Renbu area. The compositional areas shown are from Wu et al. (2010).

that crop out close to the Dazhuka conglomerate (figs. 2, 3a). These rocks yielded, respectively, 74 and 85 analyses, with ages concordant within $\pm 10 \%$, out of a total of 108 analyses for T-1 and 105 analyses for T-5 (fig. 5). Most analyses formed two clusters with ages between 130-80 and 440-400 Ma. The remaining analyses yielded significantly older ages, up to 2900 Ma. Sample T-7 was collected from the sandstone in the middle part of the northern subdomain (figs. 2, 3b). Zircon from this rock yielded ages in a range of 140-80 Ma and a scatter of older grains with ages between 2450 and $155 \mathrm{Ma}$. These results are similar to those obtained from samples
T-1 and T-5; except in the case of sample T-7, the youngest grain is somewhat younger and dates to $70 \mathrm{Ma}$ (fig. 5; tables S1, S2).

Samples (5-1, 5-2, and 5-3) were collected from a 40-m section of sedimentary strata that overlies the ophiolite in the southern subdomain (figs. 2, 3). Zircon from these rocks was also dominantly euhedral and yielded $\mathrm{Th} / \mathrm{U}$ ratios of 0.12-3.3. Eleven grains, however, had somewhat lower $\mathrm{Th} / \mathrm{U}$ values (0.03-0.09). A total of 480 analyses were undertaken on these three samples, from which 465 analyses yielded ages that were concordant within $\pm 10 \%$ (fig. 5 ). The youngest zircons from all sam-
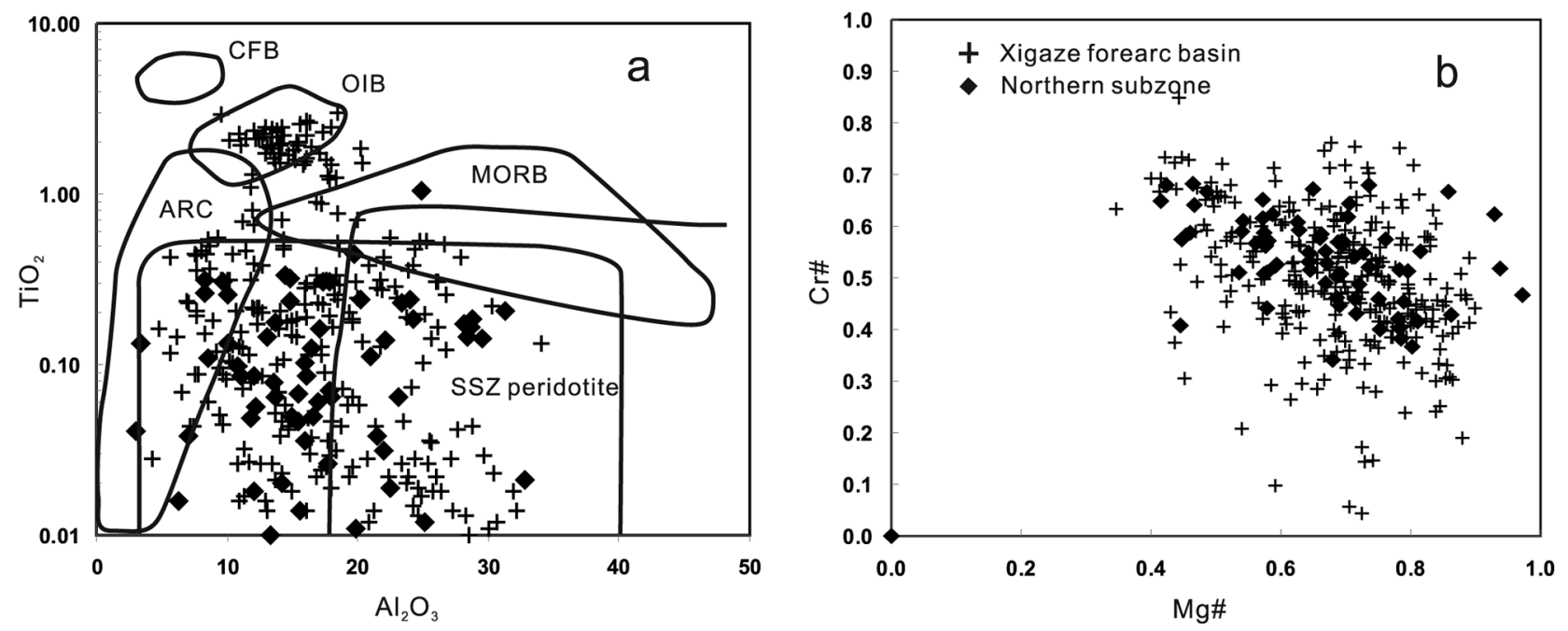

Figure 7. $a, \mathrm{TiO}_{2}$ versus $\mathrm{Al}_{2} \mathrm{O}_{3} . b, \mathrm{Cr} \#(\mathrm{Cr} /(\mathrm{Cr}+\mathrm{Mg}))$ versus $\mathrm{Mg} \#\left(\mathrm{Mg} /\left(\mathrm{Mg}+\mathrm{Fe}^{2+}\right)\right)$ diagrams for detrital Cr-spinels from the northern Renbu subzone. Data for the Xigaze forearc basin come from Hu et al. (2014). CFB, continental flood basalt; OIB, ocean-island basalt; MORB, mid-ocean ridge basalt, SSZ, supra-subduction zone. 
ples yielded ages between 70-53 $\mathrm{Ma}$, while the largest age population was between 65 and $160 \mathrm{Ma}$. Smaller populations with age ranges of 250-180 Ma, 700-490 Ma, and 1300-840 Ma were also present. The remaining grains yielded a scatter of ages between 1380 and $3560 \mathrm{Ma}$ (figs. 5, 8).

To complement the age data, 161 zircons from these samples were analyzed for Hf isotopic compositions (fig. 6). More than half of the zircons with ages $<250 \mathrm{Ma}$ yielded ${ }^{176} \mathrm{Hf} /{ }^{177} \mathrm{Hf}$ isotopic ratios of $0.28284-0.28319$ and positive $\epsilon_{\mathrm{Hf}}(t)$ values of +4.6 to +16.9 . Hf model ages for these zircons are 605 $110 \mathrm{Ma}$. The remaining Mesozoic zircons showed ${ }^{176} \mathrm{Hf} /{ }^{177} \mathrm{Hf}$ isotopic ratios of $0.28217-0.28271$ and yielded negative $\epsilon_{\mathrm{Hf}}(t)$ values of -0.8 to -16.9 and Hf model ages of 1533-786 Ma. Zircons older than $250 \mathrm{Ma}$ have ${ }^{176} \mathrm{Hf} /{ }^{177} \mathrm{Hf}$ isotopic ratios of $0.28066-$ 0.28270 and yielded $\epsilon_{\mathrm{Hf}}(t)$ values between -39.4 and +9.9. Two-stage Hf model ages for these zircons were between 3589 and $785 \mathrm{Ma}$.

Cr-Spinel Compositions. Sixty-nine Cr-spinel grains were analyzed from three samples (T-1, T-5,
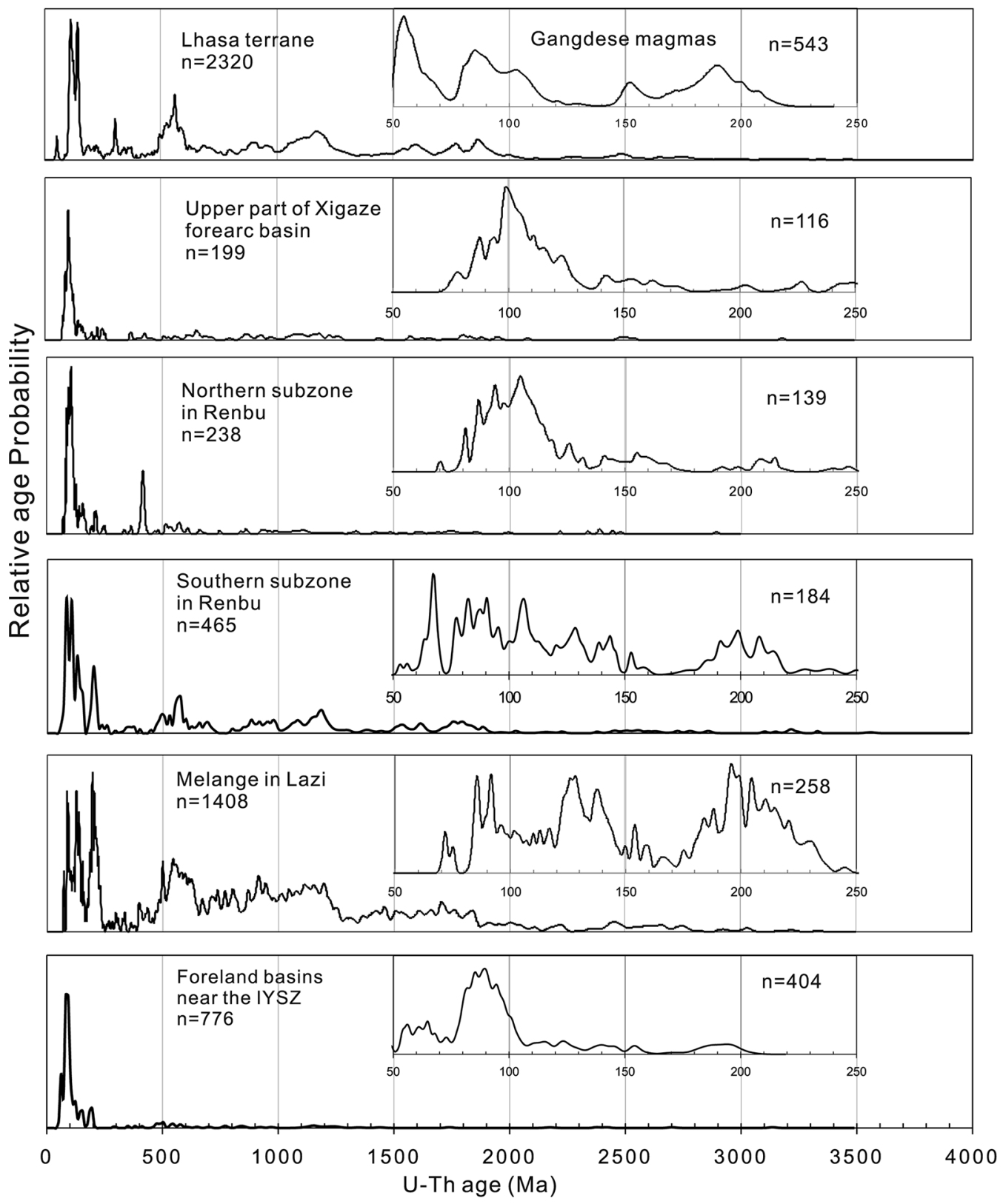

Figure 8. Detrital zircon age probability plots for all samples from the Renbu mélange zone, compared to age probability curves from the Lhasa terrane, the upper part of the Xigaze forearc, and foreland basin near the IndusYarlung suture zone (IYSZ; references in text). 
and T-7) of the northern mélange zone (fig. 2). Most spinel grains had compositions characterized by low $\mathrm{TiO}_{2}(<0.2 \mathrm{wt} \%)$, a Cr\# value $(100 \times \mathrm{Cr} /(\mathrm{Al}+\mathrm{Cr}))$ between 40 and 90, $\mathrm{Mg} \#\left(100 \times \mathrm{Mg} /\left(\mathrm{Mg}+\mathrm{Fe}^{2+}\right)\right)$ ranging from 51 to 68 , and $\mathrm{Fe}^{2+/} \mathrm{Fe}^{3+}$ ratios mainly between 0.71 and 6.82. Two exceptions preserved higher $\mathrm{Fe}^{2+} / \mathrm{Fe}^{3+}$ ratios of 20.1 and 33.3, respectively. The detrital spinels mostly plot in the "suprasubduction-zone peridotite" field (fig. 7; table S5).

\section{Discussion}

Constraining the Deposition of the Sedimentary Relicts in Renbu. Detrital zircons from both the northern and southern subdomains of the Renbu mélange zone contain a dominant age mode of 170-70 Ma. Based on the youngest zircon detrital ages, the maximum depositional age of the northern subdomain is $\sim 70 \mathrm{Ma}$, while for the southern subdomain, the maximum depositional age is $53 \mathrm{Ma}$. These results suggest that the sedimentary relicts within the Renbu tectonic mélange were deposited from the Late Cretaceous (north) or early Tertiary (south).

Given the geographic location, similarity of lithology, age patterns of detrital zircons (fig. 8; see further discussion below), and timing of deposition between the Xigaze forearc sediments and the rocks of the northern subzone, we propose that the rocks in the northern subzone likely represent part of the Xigaze forearc basin. This interpretation is supported by the close compositional match of detrital Cr-spinels in the northern subzone with those in the Xigaze forearc basin (fig. 7), which likely derive from the Lhasa terrane (Hu et al. 2014). As such, we suggest that the sediments of the northern subzone are correlatives of the upper Cretaceous Padana/Qubeiya Formation (Wu et al. 2010). The immature nature of the studied sandstones implies their derivation from proximal sources, consistent with formation as part of the Xigaze forearc basin, which is thought to be derived from the adjacent Lhasa terrane (Dürr 1996; Wu et al. 2010). As an alternative, these northern sediments may have been deposited in a trench basin when the Neo-Tethys was subducting under the south Lhasa terrane, which had a same source with the Xigaze forearc basin.

For the sandstones of the southern subzone of the mélange, abundant apatite and tremolite are also indicative of short transport distances and the presence of volcanic rocks and granites as major contributing rock types in the source region. Most of these sandstones have high lithic components, and the QtFL plots also show that their source be- longs to an orogenic provenance field. We interpret these features to suggest that the adjacent Gangdese arc to the north may be the main source for the sandstones of the southern subzone of the mélange.

U-Pb Ages of Detrital Zircon. These ideas suggested above can be further verified with reference to the isotopic compositions and age populations of the detrital zircons from various potential source regions.

The Gangdese batholith is widely exposed in the Lhasa terrane and is defined by mainly Cretaceous igneous rocks, although elements of the arc also date to the Cenozoic. Crystallization ages for the various components of the Gangdese batholith are between 260 and $8 \mathrm{Ma}$. The $\epsilon_{\mathrm{Hf}}(t)$ values for these rocks are variable, from -13.8 to +17.7 (Li et al. 2003; Chu et al. 2006; He et al. 2006; Liu et al. 2006; Zhang et al. 2007; Zhu et al. 2008, 2009, 2011; Ji et al. 2009).

In contrast to the Gangdese batholith, zircons from the Triassic and Cretaceous intrusive rocks from the central and northern Lhasa terrane have much lower, mostly negative $\epsilon_{\mathrm{Hf}}(t)$, ranging between -12.4 and +1.3 (Wu et al. 2010). Recently, Zhu et al. (2012) report that the Cambrian volcanic sequences have $\epsilon_{\mathrm{Hf}}(t)$ values in the range of -13.9 and +7.5, with $T_{\mathrm{DM}}^{\mathrm{C}}$ values ranging from 900 to $2300 \mathrm{Ma}$. PreMesozoic inherited zircons and detrital zircons from these rocks give age population peaks at 550 and $1170 \mathrm{Ma}$, show $\epsilon_{\mathrm{Hf}}(t)$ values in the range of -38.1 to 15.6, with $T_{\mathrm{DM}}^{\mathrm{C}}$ ages ranging from 300 to $3900 \mathrm{Ma}$ (Chu et al. 2006; Leier et al. 2007; Ji et al. 2009; Zhu et al. 2011; Li et al. 2014). Detrital zircon populations from the Xigaze forearc basin are characterized by a dominant age mode between 130 and $80 \mathrm{Ma}$ and a subordinate one with an age range of 190-150 Ma (Wu et al. 2010). These zircons are characterized by high ${ }^{176} \mathrm{Hf} /{ }^{177} \mathrm{Hf}$ isotopic ratios and positive $\epsilon_{\mathrm{Hf}}(t)$ values.

In the Indus-Yarlung suture zone, the zircons from gabbros exposed in the Xigaze and Zedong regions have yielded $\mathrm{U}-\mathrm{Pb}$ ages of 162 and $128-120 \mathrm{Ma}$ (Malpas et al. 2003; Dubois-Côté 2005; Wang et al. 2006; Zhong et al. 2006). Island-arc volcanic rocks in Zedang, in the eastern part of the Indus-Yarlung suture zone, yielded U-Pb ages of 161-152 Ma (McDermid et al. 2002). Detrital zircons from the mainly Late Triassic flysch of the Langiiexue Group in the Zedang-Renbu area yielded ages between 400 and $200 \mathrm{Ma}$ (Aikman et al. 2008; Li et al. 2010), while the detrital zircon population from the mélange complex in Xigaze was characterized by age modes at 230-70 Ma, 700-500 Ma, and 800-1300 Ma (Cai et al. 2012). 
The detrital zircon age pattern from the strata prior to the Late Cretaceous in Tethyan Himalaya is characterized by age peaks at $\sim 540, \sim 950$, and $\sim 1700-1500 \mathrm{Ma}$ with a wide range of $\epsilon_{\mathrm{Hf}}(t)$ values $(-29.5$ to $\sim 12.6)$ and varying $T_{\mathrm{DM}}^{\mathrm{C}}$ ages $(1000-$ $3700 \mathrm{Ma}$. Granitic basement exposed within the Himalayan gneiss domes with U-Pb ages of $\sim 500 \mathrm{Ma}$ are intruded by the $\sim 44$ to $-28 \mathrm{Ma}$ leucogranite (Lee et al. 2000; Zhang et al. 2004; Quigley et al. 2008; Myrow et al. 2010; Zeng et al. 2011). Several volcanic rocks yield U-Pb ages of 133 and $140-119 \mathrm{Ma}$ with negative $\epsilon_{\mathrm{Hf}}(t)$ values from -1.5 to -7 (Hu et al. 2010; Zhu et al. 2011). Those of the Late Cretaceousearly Cenozoic strata show a large population in the range of $160-50 \mathrm{Ma}$, which are regarded as parts of the foreland basin system near the Indus-Yarlung suture zone and derived from the Lhasa terrane (Cai et al. 2011; Wang et al. 2011; DeCelles et al. 2014).

Farther south, the rocks of the Greater Himalaya are defined predominantly by Precambrian crystalline basement. These rocks yield detrital zircons with a dominant age mode between 1300 and $900 \mathrm{Ma}$, with lesser peaks at 540, 1700-1500, and $2500 \mathrm{Ma}$, respectively (Gehrels et al. 2003, 2006; DeCelles et al. 2004).

Detrital zircons from the northern subzone of the Renbu mélange are characterized by a dominant age mode with a range of $130-80 \mathrm{Ma}$ and a series of smaller age peaks between 140 and $2890 \mathrm{Ma}$. These are comparable to the detrital zircon signatures observed for the rocks of the Xigaze forearc basin, the mélange units to the west in the Lazi area, and the younger strata in the Tethyan Himalaya (fig. 8). The rocks from all of these areas are consistent with derivation from a common source with characteristics of the Gangdese arc (Wu et al. 2010; Cai et al. 2011, 2012). Given the similarities between the data from these rocks, and those described here from the northern subzone, it seems plausible that the sedimentary relicts in the northern subzone may also represent now disrupted components of the Xigaze forearc basin and are chiefly derived from the Gangdese arc and the Lhasa terrane $(\mathrm{Wu}$ et al. 2010). This is consistent with our Cr-spinel data (fig. 7) and the sandstone petrology, which indicates that these rocks are immature and derived from a nearby orogenic source.

Detrital zircons from the southern subzone show large age peaks between $150-60$ and $220-180 \mathrm{Ma}$, which indicates that they were derived from mainly Mesozoic-aged sources. As shown in figure 6, the majority of these Mesozoic zircons reveal positive $\epsilon_{\mathrm{Hf}}(t)$ values similar to those observed for the detrital zircons from the strata of the Xigaze forearc ba$\sin (\mathrm{Wu}$ et al. 2010) and the sediments of the fore- land basins near the Indus-Yarlung suture zone. All these are considered to be mainly derived from the Lhasa terrane, especially the Gangdese arc (Ding et al. 2005; Cai et al. 2011; Wang et al. 2011). Contemporary deeper-water sedimentary basins (Zongzhuo and Sangdanlin Formations) deposited between the Cretaceous volcanic rocks in the Tethyan Himalaya and the sediments in the Renbu mélange seemingly preclude a source from those volcanic rocks in the Tethyan Himalaya. Thus, we propose the most likely source for the Mesozoic zircons to be the Gangdese arc, or partly the gabbros and volcanic rocks exposed in the ophiolite belt. Detrital zircons with ages older than $500 \mathrm{Ma}$ are also most likely derived from the Lhasa terrane, where basement of this age is locally exposed, although similar-aged rocks are also exposed in the Greater Himalaya (Gehrels et al. 2012).

Taken together, our petrologic results, Cr-spinel analyses, and detrital zircon chronologic and $\mathrm{Hf}$ isotopic constraints suggest that the upper Cretaceous sediments in the northern subzone are likely to represent tectonically disrupted relicts of the upper Xigaze forearc basin. The major source for this unit is the Lhasa terrane, particularly the Gangdese arc, although the Indus-Yarlung ophiolite may also have provided input. The Dejilin sedimentary relict from the southern subzone was probably derived from the Gangdese arc and/or recycled Xigaze forearc basin sediments. For these rocks, there is less evidence for input from the Indus-Yarlung ophiolite.

Tectonic Implications. The proposed correlation of the northern subzone Renbu sediments extends the easterly limit of the Xigaze forearc basin sediments. It suggests that the Xigaze forearc basin was probably more extensively developed within the Indus-Yarlung suture zone than currently understood, with its present distribution limited by tectonic excision during or after the collision between the Indian and Asian plates (Yin et al. 1999; Yin and Harrison 2000). The inferred setting for the southern subzone Renbu sediments, as well as for the Cretaceous relicts of the mélanges in the Lazi area (Cai et al.2012), is part of the top wedge strata and/or foreland basin on the accretionary wedge in the Indus-Yarlung suture zone. The preservation of younger strata in the Renbu mélange zone can match the Paleocene-Eocene sediments in the Saga area (Sangdanlin-Zheya formations) and Zhongba area (Tso-Jiangding Group), which is a component of a Paleocene-Eocene foreland basin (Ding et al. 2005; DeCelles et al. 2014; Hu et al. 2014). This suggests that Late Cretaceous-Tertiary sedimentary rocks probably have been broadly developed in the Indus- 
Yarlung suture zone, although only limited exposures remain as a result of more recent uplift and erosion.

Nevertheless, the units described from our studied area can be compared with the rocks of the accretionary complex in the Lazi area (Cai et al. 2012). The rocks from the Lazi area consist of the trappedophiolite, ophiolitic mélange, and offscrapped Tangga and Pomunong mélanges /Cai et al. 2012). Both mélange areas show southward younging and indicate accretionary processes were likely active along the Indus-Yarlung suture zone during the late Cretaceous and Tertiary. We suggest that these accretionary units could have been produced in a single north-dipping subduction zone beneath the southern margin of the Lhasa terrane (Cai et al. 2012), rather than formed in an intraoceanic arc during the Eocene (Aitchison et al. 2007).
To summarize the evolution of the Renbu mélange zone, we suggest that in the Cretaceous, the Xigaze ophiolite was obducted to the south and became the basement of the Xigaze basin (Wang et al. 2012). Subsequent to this, uplift of the Lhasa terrane exposed the Gangdese arc and the rocks of the Lhasa terrane into which these arc rocks were intruded, and erosion led to the sourcing of detritus from this area, which was deposited in the Xigaze forearc basin (Wu et al. 2010; fig. 9a). By the Late Cretaceous, mélange accretion was complete (Cai et al. 2012) and the Xigaze forearc basin was filled (Einsele et al. 1994; Wan et al. 1997). Detrital material from the Lhasa terrane would have been progressively uplifted and transported southward and deposited in the trench, forming parts of the sedimentary relicts in the Renbu mélange zone (southern subzones) and upper Zongzhou/Sang-

\section{a. Late Cretaceous}

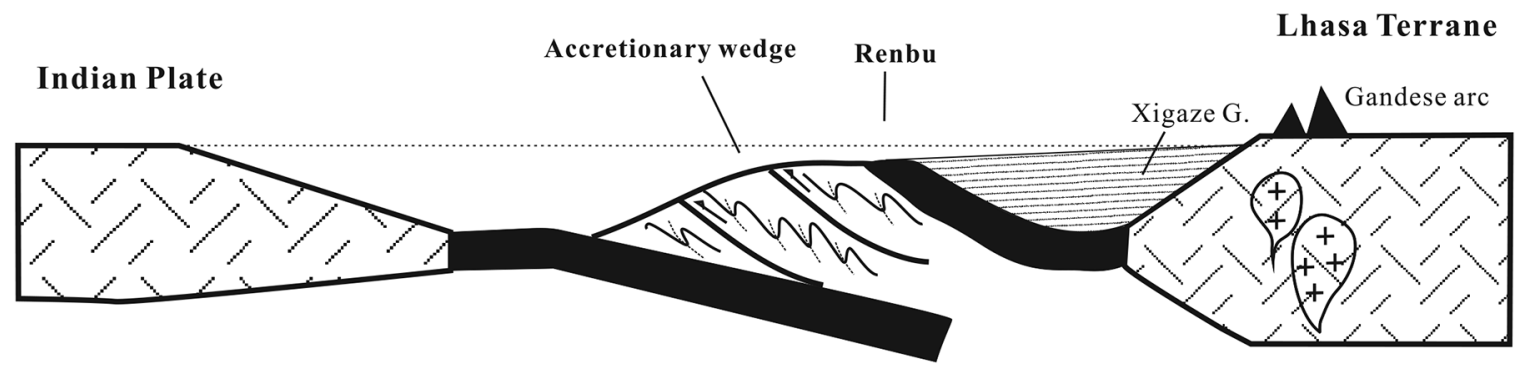

\section{b.Paleocene to Early Eocene}

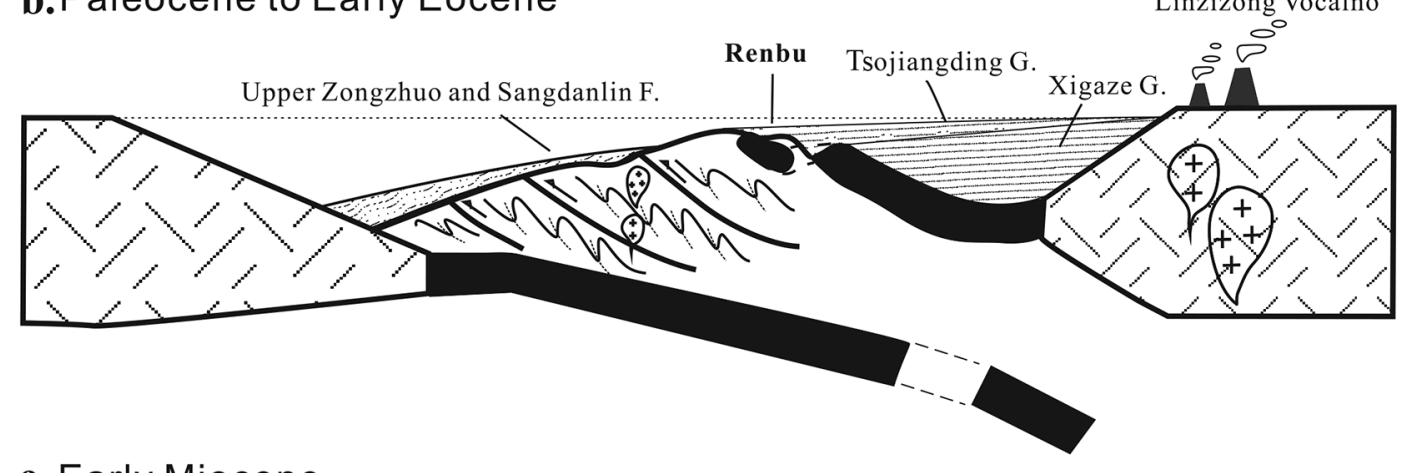

c. Early Miocene

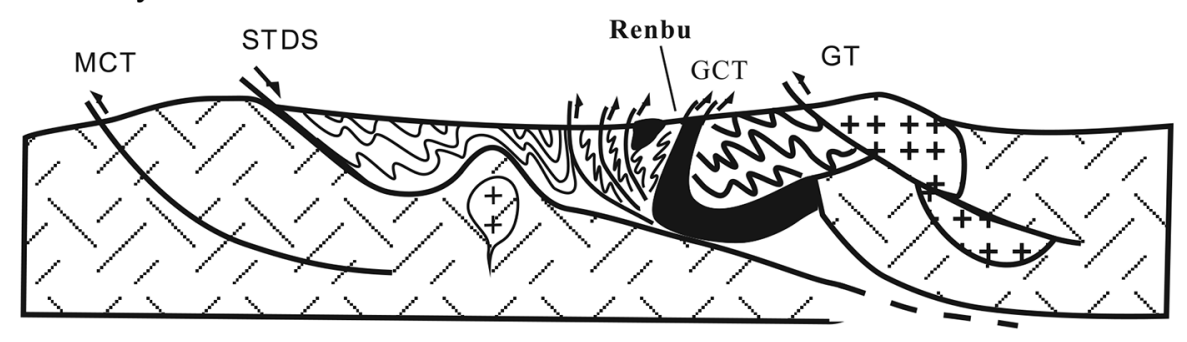

Figure 9. Tectonic schematic of subduction accretion along the Indus-Yarlung suture zone from the Upper Cretaceous to Early Miocene. MCT, Main Central Thrust; STDS = South Tibetan detachment system; GCT, Great Counter Thrust; GT, Gandese Thrust. 
danlin Formation in the Tethyan Himalaya. Following the India-Asia collision during the Paleocene (Ding et al. 2005; Najman et al. 2010), the topmost sediments were deposited on the accretionary wedge in the Renbu area, as a wedge-top of the foreland basin system continuously received the sediments from the north and conveyed the Asian materials onto the Indian continental margin (fig. 9b). Subsequent India-Asia convergence and deformation led to parts of the northern accretion being overthrust onto the Xigaze basin strata and mixed with the Xigaze forearc basin strata during the activity of the Great Counter Thrust in the Miocene (19-10 Ma; fig. 9c). Most main-fault systems of the Himalaya-Tibet orogenic belt in south Tibet were activated at this period (Yin et al. 2006).

\section{Conclusions}

Late Cretaceous to early Tertiary sediments in the Renbu area were deposited in/on the accretionary complex along the Indus-Yarlung suture zone prior to and during the initial India-Asia collision. As with sedimentary remnants in the mélanges farther west in the Xigaze area, the Renbu mélange sediments preserve petrographic and geochemical signatures consistent with a Lhasa terrane provenance to the north. While still conjecture, the youngest strata in the Renbu melange are likely to represent a remnant of an early postcollisional foreland basin developed along the Indus-Yarlung suture zone during early Cenozoic time.

\section{A C KNOW LED G MENTS}

We thank anonymous reviewers and Editor David B. Rowley, whose careful and thorough comments significantly improved this article. We are grateful to A. Greg and J. Woodhead for help with zircon $\mathrm{U}-\mathrm{Pb}$ and $\mathrm{Hf}$ isotope experiments. This study was financially supported by grants from the Australia Research Council (Discovery Early Career Research Award; DE120102245), Geological Survey of China (1212011121275), and the basic foundation of the Institute of Geology, Chinese Academy of Geological Science (J1108).

\section{REFEREN CES CITED}

Aikman, B. A.; Harrison, T. M.; and Ding, L. 2008. Evidence for early (>44 Ma) Himalayan crustal thickening, Tethyan Himalaya, southeastern Tibet. Earth Planet. Sci. Lett. 274:14-23.

Aitchison, J. C. 2000. Remnants of a Cretaceous intraoceanic subduction system within the Yarlung-Zangbo suture (south Tibet). Earth Planet. Sci. Lett. 183:231244.

Aitchison, J. C.; Ali, J. R.; and Davis, A. M. 2007. When and where did India and Asia collide? J. Geophys. Res. 112:B05423, doi:10.1029/2006JB004706.

Bichert-Toft, J., and Albarède, F. 1997. The Lu-Hf isotope geochemistry of chondrites and the evolution of the mantle-crust system. Earth Planet. Sci. Lett. 148:243258.

Burg, J. P., and Chen, G. 1984. Tectonics and structure zonation of southern Tibet, China. Nature 311:219223.

Cai, F.; Ding, L.; Leary, R. J.; Wang, H.; Xu, Q.; Zhang, L.; and Yue, Y. 2012. Tectonostratigraphy and provenance of an accretionary complex within the YarlungZangpo suture zone, southern Tibet: insights into subduction-accretion processes in the Neo-Tethys. Tectonophysics 574-575:181-192.

Cai, F.; Ding, L.; and Yue, Y. 2011. Provenance analysis of upper Cretaceous strata in the Tethys Himalaya, southern Tibet: implications for timing of India-Asia collision. Earth Planet. Sci. Lett. 305:195-206. doi:10 .1016/j.epsl.2011.02.055.

Chen, Z.; Liu, Y.; Hodges, K. V.; Burchfiel, B. C.; Royden, L. H.; and Deng, C. 1990. The Kangmar dome: a metamorphic core complex in southern Xizang (Tibet). Science 250:1552-1556.

Chu, M. F.; Chung, S. L.; Song, B.; Liu, D. Y.; O'Reilly, S. Y.; Pearson, N. J.; Ji, J. Q.; and Wen, D. J. 2006. Zircon $\mathrm{U}-\mathrm{Pb}$ and $\mathrm{Hf}$ isotope constraints on the Mesozoic tectonics and crustal evolution of southern Tibet. Geology 34:745-748.

Davis, A. M.; Aitchison, J. C.; Zhu, B. D.; Luo, H.; and Sergei, Z. 2002. Paleogene island arc collision-related conglomerates, Yarlung-Tsangpo suture zone, Tibet. Sediment. Geol. 150:247-273.

DeCelles, P.; Gehrels, G.; Najman, Y.; Martin, A. J.; Carter, A.; and Garzanti, E. 2004. Detrital geochronology and geochemistry of Cretaceous-Early Miocene strata of Nepal: implications for timing and diachroneity of initial Himalayan orogenesis. Earth Planet. Sci. Lett. 227:313-330.

DeCelles, P.; Kapp, P.; Gehrels, G.; and Ding, L. 2014. Paleocene-Eocene foreland basin evolution in the Himalaya of southern Tibet and Nepal: implications for the age of initial India-Asia collision. Tectonics 33: 824-849. doi:10.1002/2014TC003522.

DeCelles, P. G.; Gehrels, G. E.; Quade, J.; LaReau, B.; and Spurlin, M. 2000. Tectonic implications of U-Pb zircon ages of the Himalayan orogenic belt in Nepal. Science 288:497-499.

Dewey, J. F.; Sharkleton, R. M.; Chang, C. F.; and Sun, Y. Y. 1988. The tectonic evolution of the Tibetan plateau. Philos. Trans. R. Soc. Lond. 327:313-330.

Dickinson, W. R. 1985. Interpreting provenance relations from detrital modes of sandstones. In Zuffa, 
G. G., ed. Provenance of Arenites. Reidel, Dordrecht, p. 333-361.

Ding, L. 2003. Paleocene deep-water sediments and radiolarian faunas: implications for evolution of YarlungZangbu foreland basin, southern Tibet. Sci. China Earth Sci. 46:84-96.

Ding, L.; Cai, F.; Zhang, Q.; Zhang, L.; Xu, Q.; Yang, D.; Liu, D.; and Zhong, D. 2009. Provenance and tectonic evolution of the foreland basin systems in the GandeseHimalayan collisional orogen belt. Chinese J. Geol. 44:1289-1311 (in Chinese with English abstract).

Ding, L.; Kapp, P.; and Wan, X. 2005. Paleocene-Eocene record of ophiolite obduction and initial India-Asia collision, south central Tibet. Tectonics 24. doi:10 .1029/2004TC001729.

Dubois-Côté, V.; Hébert, R.; Dupuis, C.; Wang, C. S.; Li, Y.; and Dostal, J. 2005. Petrological and geochemical evidence for the origin of the Yarlung Zangbo ophiolites, southern Tibet. Chem. Geol. 214:265-286.

Dunkl, I.; Antolín, B.; Wemmer, K.; Rantitsch, G.; Kienast, M.; Montomoli, C.; Ding, L.; Carosi, R.; Appel, E.; Elbay, R.; Xu, Q.; and Von Eynatten, H. 2011. Metamorphic evolution of the Tethyan Himalayan flysch in SE Tibet. Geol. Soc. Lond. Spec. Publ. 353:4569.

Dürr, S. B. 1996. Provenance of Xigaze fore-arc basin clastic rocks (Cretaceous, south Tibet). Geol. Soc. Am. Bull. 108:669-684.

Eggins, S. M.; Grün, R.; McCulloch, M. T.; Pike, A. W. G.; Chappell, J.; Kinsley, L.; Mortimer, G.; Shelley, M.; Murray-Wallace, C. V.; and Spötl, C. 2005. In situ Useries dating by laser-ablation multi-collector ICPMS: new prospects for Quaternary geochronology. Quat. Sci. Rev. 24:2523-2538. doi:10.1016/j.quascirev.2005 .07 .006

Einsele, G.; Liu, B.; Dürr, S.; Frisch, W.; Liu, G.; Luterbacher, H. P.; Ratschbacher, L.; Ricken, W.; Wendt, J.; Wetzel, A.; Yu, G.; and Zheng, H. 1994. The Xigaze forearc basin: evolution and facies architecture (Cretaceous, Tibet). Sediment. Geol. 90:1-32.

Fang, A.; Yan, Z.; Liu, X.; Tao, J.; Li, J.; and Pan, Y. 2006. The age of the plant fossil assemblage in the Liuqu Conglomerate of southern Tibet and its tectonic significance. Prog. Nat. Sci. 16:55-64.

Gehrels, G. E.; DeCelles, P. G.; Martin, A.; Ojha, T. P.; Pinhassi, G.; and Upreti, B. N. 2003. Initiation of the Himalayan Orogen as an early Paleozoic thin-skinned thrust belt. GSA Today 13:4-9.

Gehrels, G. E.; DeCelles, P. G.; Ojha, T. P.; and Upreti, B. N. 2006. Geologic and U-Th-Pb geochronologic evidence for early Paleozoic tectonism in the Kathmandu thrust sheet, central Nepal Himalaya. Geol. Soc. Am. Bull. 118:185-198.

Gehrels, G. E.; Kapp, P.; DeCelles, P.; Blakey, R.; Weislogel, A.; Ding, L.; Guynn, J.; Martin, A.; McQuarrie, N.; and Yin, A. 2012. Detrital zircon geochronology of pre-Tertiary strata in the Tibetan-Himalayan orogen. Tectonics. doi:10.1029/2011TC002868.

Griffin, W. L.; Pearson, N. J.; and Belousova, E. 2000. The $\mathrm{Hf}$ isotope composition of cratonic mantle: LAM-MC-
ICPMS analysis of zircon megacrysts in kimberlites. Geochim. Cosmochim. Acta 64:133-147.

Guynn, J. H.; Kapp, P.; Pullen, A.; Heizler, M.; Gehrels, G.; and Ding, L. 2006. Tibetan basement rocks near Amdo reveal "missing" Mesozoic tectonism along the Bangong suture, central Tibet. Geology 34:505-508.

Harris, N. B. W.; Xu, R. H.; Lewis, C. L.; Hawkeworth, C. J.; and Zhang, Y. 1988. Isotope geochemistry of the 1985 Tibet Geotraverse Lhasa to Golmud. Philos. Trans. R. Soc. Lond. A 327:263-285.

He, Z. H.; Yang, D. M.; Zheng, C. Q.; and Wang, T. W. 2006. Isotopic dating of the Mamba granitoid in the Gangdise tectonic belt and its constraint on the subduction time of the Neotethys. Geol. Rev. 52:100-106 (in Chinese with English abstract).

Hébert, H.; Bezard, R.; Guilmette, C.; Dostal, J.; Wang, C. S.; and Liu, Z. F. 2012. The Indus-Yarlung Zangbo ophiolites from Nanga Parbat to Namche Barwa syntaxes, southern Tibet: first synthesis of petrology, geochemistry, and geochronology with incidences on geodynamic reconstructions of Neo-Tethys. Gondwana Res. 22:377-397. doi:10.1016/j.gr.2011.10.013.

Hellstrom, J. 2008. Iolite: software for spatially resolved LA-(quad and MC) ICPMS analysis. In Sylvester P., ed. The earth sciences: current practices and outstanding issues. Mineralogical Association of Canada, Québec, Quebec, p. 343-348.

$\mathrm{Hu}$, J. 2002. 1:250000 regional geological investigation of Xigaze, Xizang. Beijing, Geological Publishing House, 258 p. (in Chinese).

Hu, X. M.; An, W.; Wan, J. G.; Garzanti, E.; and Guo, R. H. 2014. Himalayan detrital chromian spinels and timing of Indus-Yarlung ophiolite erosion. Tectonophysics 621:60-68.

Hu, X. M.; Jansa, L.; Chen, L.; Griffin, W. L.; O'Reilly, S. Y.; and Wang, J. G. 2010. Provenance of Lower Cretaceous Wolong volcaniclastics in the Tibetan Tethyan Himalaya: implications for the final breakup of eastern Gondwana. Sediment. Geol. 223:193205.

Ji, W. Q.; Wu, F. Y.; Chung, S. L.; Li, J.; and Liu, C. Z. 2009. Zircon U-Pb geochronology and $\mathrm{Hf}$ isotopic constraints on petrogenesis of the Gangdese batholith, southern Tibet. Chem. Geol. 262:229-245.

Lee, J.; Hacker, B. R.; Dinklage, W. S.; Wang, Y.; Gans, P.; Calvert, A.; Wan, J.; Chen, W.; Blythe, A. E.; and McClelland, W. 2000. Evolution of the Kangmar dome, southern Tibet: structural, petrologic, and thermochronologic constraints. Tectonics 19:872-895.

Lee, J.; Hacker, B.; and Wang, Y. 2004. Evolution of North Himalayan gneiss domes: structural and metamorphic studies in Mabja Dome, southern Tibet. J. Struct. Geol. 26:2297-2316.

Leier, A. L.; Kapp, P.; Gehrels, G. E.; and DeCelles, P. G. 2007. Detrital zircon geochronology of CarboniferousCretaceous strata in the Lhasa terrane, southern Tibet. Basin Res. 19:361-378.

Li, C.; Wang, T. W.; Li, H. M.; and Zeng, Q. G. 2003. Discovery of Indosinian megaporphyritic granodiorite in the Gangdise area: evidence for the existence of Paleo- 
Gangdise. Geol. Bull. China 22:364-366 (in Chinese with English abstract).

Li, G. W.; Liu, X. H.; Alex, P.; Wei, L. J.; Liu, X. B.; Huang, F. X.; and Zhou, X. J. 2010. In-situ detrital zircon geochronology and Hf isotopic analyses from Upper Triassic Tethys sequence strata. Earth Planet. Sci. Lett. 297:461-470.

Li, G. W.; Liu, X. H.; Wei, L. J.; and Liu, X. B. 2011. Discovery of the Late Cretaceous detrital zircon in Renbu tectonic mélange, South Tibet and its tectonic significance. Acta Petrol. Sin. 27:3328-3334 (in Chinese with English abstract).

Li, G. W.; Sandiford, M.; Liu, X.; Xu, Z.; Wei, L.; and Li, H. 2014. Provenance of the Late Triassic sediments in Central Lhasa terrane, Tibet and its implication. Gondwana Res. 25:1680-1689.

Liu, G., and Ensele, G. 1994. Sedimentary history of the Tethyan basin in the Tibetan Himalayas. Geol. Rundsch. 82:32-61.

Liu, Q. X.; Jiang, W.; Jian, P.; Ye, P. S.; Wu, Z. H.; and $\mathrm{Hu}, \mathrm{D}$. G. 2006. Zircon SHRIMP U-Pb age and petrochemical and geochemical features of Mesozoic muscovite monzonitic granite at Ningzhong, Tibet. Acta Petrol. Sin. 22:643-652 (in Chinese with English abstract).

Ludwig, K. R. 2003. User's manual for Isoplot 3.0: a geochronological toolkit for Microsoft Excel. Special publication 4. Berkeley Geochronology Center, $71 \mathrm{p}$.

Malpas, J.; Zhou, M. F.; Robinson, P. T.; and Reynolds, P. H. 2003. Geochemical and geochronological constraints on the origin and emplacement of the Yarlung Zangbo ophiolites, southern Tibet. Geol. Soc. Lond. Spec. Publ. 218:191-206.

McDermid, I. R.; Aitchison, J. C.; Davis, A. M.; Harrison, T. M.; and Grove, M. 2002. The Zedong terrane: a Late Jurassic intra-oceanic magmatic arc within the Yarlung-Zangbo suture zone, southeastern Tibet. Chem. Geol. 187:267-277.

Miller, C.; Thoni, M.; Frank, W.; Schuster, R.; Melcher, F.; Meisel, T.; and Zanetti, A. 2003. Geochemistry and tectonomagmatic affinity of the Yungbwa ophiolite, SW Tibet. Lithos 66:155-172.

Mo, X. X.; Hou, Z. Q.; Niu, Y. L.; Dong, G. C.; Qu, X. M.; Zhao, Z. D.; and Yang, Z. M. 2007. Mantle contributions to crustal thickening during continental collision: evidence from Cenozoic igneous rocks in southern Tibet. Lithos 96:225-242.

Morton, A. C., and Hallsworth, C. R. 1994. Identifying provenance-specific features of detrital heavy mineral assemblages in sandstones. Sediment. Geol. 90:241256.

Myrow, P. M.; Hughes, N. C.; Goodge, J. W.; Fanning, C. M.; Williams, I. S.; Pengm, S. C.; Bhargava, O. N.; Parcha, S. K.; and Pogue, K. R. 2010. Extraordinary transport and mixing of sediment across Himalayan central Gondwana during the Cambrian-Ordovician. Geol. Soc. Am. Bull. 122:1660-1670.

Najman, Y. 2006. The detrital record of orogenesis: a review of approaches and techniques used in the Himalayan sedimentary basins. Earth Sci. Rev. 74:1-72.
Najman, Y.; Appel, E.; Boudagher-Fadel, M.; Bown, P.; Carter, A.; Garzanti, E.; Godin, L.; Han, J. T.; Liebke, U.; Oliver, G.; Parrish, R.; and Vezzoli, G. 2010. Timing of India-Asia collision: geological, biostratigraphic, and palaeomagnetic constraints. J. Geophys. Res. 115: B12416. doi:10.1029/2010JB007673.

Paton, C.; Woodhead, J. D.; Hellstrom, J. C.; Hergt, J. M.; Greig, A.; and Maas, R. 2010. Improved laser ablation $\mathrm{U}-\mathrm{Pb}$ zircon geochronology through robust downhole fractionation correction. Geochem. Geophys. Geosyst. 11:Q0AA06. doi:10.1029/2009GC002618.

Quigley, M. C.; Yu, L. J.; Gregory, C.; Corvino, A.; Sandiford, M.; Wilson, C. J. L.; Liu, X. H. 2008. U-Pb SHRIMP zircon geochronology and $\mathrm{T}$ - $\mathrm{t}$-d history of the Kampa Dome, southern Tibet. Tectonophysics 446:97-113.

Scherer, E.; Munker, C.; and Mezger, K. 2001. Calibration of the lutetium-hafnium clock. Science 293:683687.

Wan, X., and Ding, L. 2002. Discovery of the latest Cretaceous planktonic foraminifera from Gyirong of southern Tibet and its chronostratigraphic significance. Acta Palaeontol. Sin. 41:89-95.

Wan, X. Q.; Wang, C. S.; and Wang, L. 1997. Discovery of Cretaceous foraminifera in the Xigaze forearc basin, Xizang-with a chronostratigraphic discussion. Acta Geol. Sin. 71:193-201 (in Chinese with English abstract).

Wang, C. S.; Li, X. H.; Liu, Z. F.; Li, Y. L.; Jansa, L.; Dai, J. G.; and Wei, Y. 2012. Revision of the CretaceousPaleogene stratigraphic framework, facies architecture and provenance of the Xigaze forearc basin along the Yarlung Zangbo suture zone. Gondwana Res. 22:415-433. doi:10.1016/j.gr.2011.09.014.

Wang, J. G.; Hu, X. M.; Garzanti, E.; and Wu, F. Y. 2013. Upper Oligocene-Lower Miocene Gangrinboche conglomerate in the Xigaze area, southern Tibet: implications for Himalayan uplift and Paleo-YarlungZangbo initiation. J. Geol. 121:425-444.

Wang, J. G.; Hu, X. M.; Jansa, L.; and Huang, Z. C. 2011. Provenance of the Upper Cretaceous-Eocene deepwater sandstones in Sangdanlin, southern Tibet: constraints on the timing of initial India-Asia collision. J. Geol. 119:293-309. doi:10.1086/659145.

Wang, R.; Xia, B.; Zhou, Q. G.; Zhang, Y. Q.; Yang, Z. Q.; Li, W. Q.; and Wei, D. L. 2006. SHRIMP zircon U-Pb dating for gabbro from the Tiding ophiolite in Tibet. Chinese Sci. Bull. 51:1776-1779.

Wei, L. J.; Liu, X. H.; Yan, F. H.; Mai, X. S.; Li, G. W.; Liu, X. B.; and Zhou, X. J. 2011. Palynological evidence sheds new light on the age of the Liuqu Conglomerates in Tibet and its geological significance. Sci. China Earth Sci. 54:901-911.

Willems, H.; Zhou, Z.; Zhang, B.; and Grafe, K. U. 1996. Stratigraphy of the upper Cretaceous and lower tertiary strata in the Tethyan Himalayas of Tibet (Tingri area, China). Geolog. Rundsch. 85:723-754.

Woodhead, J.; Hergt, J.; Shelley, M.; Eggins, S.; and Kemp, R. 2004. Zircon Hf-isotope analysis with an excimer laser, depth profiling, ablation of complex geometries, 
and concomitant age estimation. Chem. Geol. 209: 121-135. doi:10.1016/j.chemgeo.2004.04.026.

Woodhead, J. D.; Hellstrom, J.; Hergt, J.; Greig A.; and Maas, R. 2007. Isotopic and elemental imaging of geological materials by laser ablation inductively coupled plasma-mass spectrometry. Geostand. Geoanal. Res. 31:331-343.

Wu, F. Y.; Ji, W. Q.; Liu, C. Z.; and Chung, S. L. 2010. Detrital zircon $\mathrm{U}-\mathrm{Pb}$ and $\mathrm{Hf}$ isotopic data from the Xigaze fore-arc basin: constraints on Transhimalayan magmatic evolution in southern Tibet. Chem. Geol. 271:13-25.

Yang, J.; Xu, Z.; Li, Z.; Xu, X.; Li, T.; Ren, Y.; Li, H.; Chen, S.; and Robinson, R. T. 2009. Discovery of an eclogite belt in the Lhasa block, Tibet: a new border for PaleoTethys? J. Asian Earth Sci. 34:76-89.

Yin, A. 2006. Cenozoic tectonic evolution of the Himalayan orogen as constrained by along-strike variation of structural geometry, exhumation history, and foreland sedimentation. Earth Sci. Rev. 76:1-131.

Yin, A., and Harrison, T. M. 2000. Geologic evolution of the Himalayan-Tibetan orogen. Annu. Rev. Earth Planet. Sci. 28:211-280

Yin, A.; Harrison T. M.; Murphy M. A.; Grove, M.; Ryerson, F. J.; Wang, X.; and Chen, Z. 1999. Tertiary deformation history of southeastern and southwestern Tibet during the Indo-Asian collision. Geol. Soc. Am. Bull. 111:1644-1664.

Zeng, L.; Gao, L.; Xie, K.; and Liu-Zeng, J. 2011. MidEocene high $\mathrm{Sr} / \mathrm{Y}$ granites in the Northern Himalayan gneiss domes: melting thickened lower continental crust. Earth Planet. Sci. Lett. 303:251-266.

Zhang, H. F.; Harris, N.; Parrish, R.; Zhang, L.; and Zhao, Z. D. 2004. U-Pb ages of Kude and Sajia leucogranites in Sajia dome from North Himalaya and their geological implications. Chinese Sci. Bull. 49:20872092.

Zhang, H. F.; Xu, C. W.; Guo, J. Q.; Zong, K. Q.; Cai, H. M.; and Yuan, H. L. 2007. Indosinian orogenesis of the Gangdise Terrane: evidences from zircon dating and petrogenesis of granitoids. Earth Sci. J. China Univ. Geosci. 32:155-166 (in Chinese with English abstract).

Zhong, L.; Xia, B.; Zhou, Q.; Zhang, Y.; Wang, R.; Wei, D.; and Yang, Z. 2006. SHRIMP zircon U-Pb dating for gabbro from the Luobusha ophiolite in Tibet. Geol. Rev. 52:224-229 (in Chinese with English abstract).

Zhu, D. C.; Mo, X. X.; Niu, Y. L.; Zhao, Z. D.; Wang, L. Q.; Pan, G. T.; and Wu, F. Y. 2009. Zircon U-Pb dating and in-situ Hf isotopic analysis of Permian peraluminous granite in the Lhasa terrane, southern Tibet: implications for Permian collisional orogeny and paleogeography. Tectonophysics 469:48-60.

Zhu, D. C.; Pan, G. T.; Chun, S. L.; Liao, Z. L.; Wang, L. Q.; and Li, G. M. 2008. SHRIMP zircon age and geochemical constraints on the origin of early Jurassic volcanic rocks from the Yeba Formation, southern Gangdese in south Tibet. Int. Geol. Rev. 50:442-471.

Zhu, D. C.; Zhao, Z. D.; Niu, Y. L.; Dilek, Y.; Hou, Z. Q.; and Mo, X. X. 2013. The origin and pre-Cenozoic evolution of the Tibetan Plateau. Gondwana Res. 23: 1429-1454.

Zhu, D. C.; Zhao, Z. D.; Niu, Y. L.; Dilek, Y.; Wang, L. Q.; and Mo, X. X. 2011. Lhasa terrane in southern Tibet came from Australia. Geology 39:727-730.

Zhu, D. C.; Zhao, Z. D.; Niu, Y. L.; Dilek, Y.; Wang, Q.; Ji, W. H.; Dong, G. C.; et al. 2012. Cambrian bimodal volcanism in the Lhasa Terrane, southern Tibet: record of an early Paleozoic Andean-type magmatic arc in the Australian proto-Tethyan margin. Chem. Geol. 328:290-308. 
Copyright of Journal of Geology is the property of University of Chicago Press and its content may not be copied or emailed to multiple sites or posted to a listserv without the copyright holder's express written permission. However, users may print, download, or email articles for individual use. 


\section{University Library}

\section{- M M N E R VA A gateway to Melbourne's research publications}

Minerva Access is the Institutional Repository of The University of Melbourne

Author/s:

Li, G;Sandiford, M;Boger, S;Liu,;Wei, L

Title:

Provenance of the Upper Cretaceous to Lower Tertiary Sedimentary Relicts in the Renbu Mélange Zone, within the Indus-Yarlung Suture Zone

Date:

2015

Citation:

Li, G., Sandiford, M., Boger, S., Liu, \& Wei, L. (2015). Provenance of the Upper Cretaceous to Lower Tertiary Sedimentary Relicts in the Renbu Mélange Zone, within the Indus-Yarlung Suture Zone. The Journal of Geology, 123 (1), pp.39-54. https://doi.org/10.1086/680207.

Persistent Link:

http://hdl.handle.net/11343/116570 